(10.21704/pja.v4i2.154

http://revistas.lamolina.edu.pe/index.php/jpagronomy/index

(C) The authors. Published by Universidad Nacional Agraria La Molina

\title{
Physicochemical and microbiological quality of honeys produced by stingless bees Scaptotrigona polysticta, Melipona illota and Tetragonisca angustula (Apidae: Meliponini) in San Martín, Peru
}

Calidad físico - química y microbiológica de las mieles producidas por las abejas sin aguijón Scaptotrigona polysticta, Melipona illota y Tetragonisca angustula (Apidae: Meliponini) en San Martín, Perú

\author{
Marilena Marconi ${ }^{1 *}$; Javier Ormeño Luna ${ }^{2}$; Carlos Daniel Vecco Giove \\ *Corresponding author: marilena.marconi@gmail.com \\ https://orcid.org/0000-0001-6691-1921
}

\begin{abstract}
The honeys from stingless bees (Hymenoptera: Apidae: Meliponini) are recognized for their medicinal properties. They are commonly used by many indigenous groups around the world. However, in Peru stingless beekeeping is practiced in an artisanal way and the honeys remain products whose qualities are still little studied. The objective of this work was to analyze physicochemical characteristics and microbiological quality of honeys produced by Scaptotrigona polysticta Moure, Melipona illota Cockerell and Tetragonisca angustula Latreille in apiaries of department of San Martin, Peru. In June and November 2019, 30 honey samples were collected from 24 colonies housed in two apiaries in the towns of Tarapoto and Chasuta. Significant differences $(\mathrm{p}<0,05)$ were found for $\mathrm{pH}(3,8 \pm 0,6 ; 3,5 \pm 0,6 ; 4,7 \pm 0,6)$ and the percentage of total solutes $(70,4 \pm 2,5 \% ; 61,2 \pm 3,2 \% ; 73,0 \pm 2,7 \%)$, among the honey samples of S. polysticta, M. illota. and T. angustula, respectively. The color of $S$. polysticta honey was variable, from light amber to dark yellow (115 \pm 23 $\mathrm{mm}$ Pfund), while T. angustula honey was darker yellow (178 $\pm 33 \mathrm{~mm}$ Pfund). Values for mesophilic and anaerobic sulfite-reducing microorganisms were under the level of $1 \mathrm{CFU} / \mathrm{mL}$ for all species. Fungi and yeasts exceeded the allowed value ( $>10 \mathrm{CFU} / \mathrm{mL}$ ) according Peruvian sanitary norm № 071-Minsa/Digesa-V.01, in 30 and 50\% of the samples of $S$. polysticta and T. angustula, respectively. These results contribute to the knowledge of the stingless bee honeys of Peru providing important references for the quality standard setting process and the advancement of stingless beekeeping.
\end{abstract}

Keywords: Meliponini, honeys, Peruvian Amazon, Tarapoto, meliponiculture.

\section{Resumen}

Las mieles de abejas sin aguijón (Hymenoptera: Apidae: Meliponini) son reconocidas por sus propiedades medicinales y comúnmente utilizadas por muchos grupos indígenas de todo el mundo. Sin embargo, la crianza de abejas sin aguijón en el Perú se practica de forma artesanal y las mieles son productos de cualidades aún poco estudiadas. El objetivo de este trabajo fue analizar las características fisicoquímicas y la calidad microbiológica de las mieles producidas por Scaptotrigona polysticta Moure, Melipona illota Cockerell y Tetragonisca angustula Latreille en apiarios del departamento de San Martín, Perú. En junio y noviembre de 2019 se recolectaron 30 muestras de miel de 24 colonias alojadas en dos colmenares en las localidades de Tarapoto y Chasuta. Se encontraron diferencias significativas $(\mathrm{p}<0,05)$ para el $\mathrm{pH}(3,8 \pm 0,6 ; 3,5 \pm 0,6 ; 4,7 \pm 0,6)$ y el porcentaje de solutos totales $(70,4 \pm 2,5 \% ; 61,2 \pm 3,2 \% ; 73,0 \pm 2,7 \%)$, entre las muestras de miel de S. polysticta, M. illota. y T. angustula, respectivamente. El color de la miel de $S$. polysticta varió de ámbar claro a amarillo oscuro (115 $\pm 23 \mathrm{~mm}$ Pfund), mientras que lo de la miel de T. angustula se presentó amarillo

Cite this article:

Marconi, M., Ormeño, J., \& Vecco, D. (2020). Physicochemical and microbiological quality of honeys produced by stingless bees Scaptotrigona polysticta, Melipona illota and Tetragonisca angustula (Apidae: Meliponini) in San Martín, Peru. Peruvian Journal of Agronomy, 4(2):55-60. http://dx.doi.org/10.21704/pja.v4i2.1541

\footnotetext{
${ }^{1}$ Urku Estudios Amazónicos. Tarapoto, Perú.

E-mail: marilena.marconi@gmail.com; https://orcid.org/0000-0001-6691-1921

E-mail: carvec2@gmail.com; https://orcid.org/0000-0003-2705-823X

${ }^{2}$ Universidad Nacional de San Martín, Laboratorio de Apicultura. Tarapoto, Perú.

E-mail: javierol@unsm.edu.pe; https://orcid.org/0000-0003-3584-1451
} 
más oscuro (178 $\pm 33 \mathrm{~mm}$ Pfund). Los valores de microorganismos mesófilos y anaerobios sulfitos reductores estuvieron por debajo del nivel de $1 \mathrm{UFC} / \mathrm{mL}$ para todas las mieles. Los hongos y levaduras excedieron el valor permitido ( $>10$ UFC / mL) según la norma sanitaria peruana № 071-Minsa/Digesa-V.01, en 30 y 50\% de las muestras de $S$. polysticta y $T$. angustula, respectivamente. Estos resultados contribuyen al conocimiento de las mieles de abejas sin aguijón del Perú, al proporcionar referencias para establecer estándares de calidad que promuevan el avance de la meliponicultura.

\section{Introduction}

Meliponini (Hymenoptera: Apidae), commonly called stingless bees, are important pollinators that inhabit the tropical and subtropical areas of the world (Yáñez-Ordóñez et al., 2008). In the Amazon region, these insects would pollinate $38 \%$ of all plant species (Kerr et al., 2001).

Since the time of the Maya, the Meliponini were managed for production of honey, whose antioxidative (Cauich et al., 2015), antiseptic, antimicrobial, anticancer and anti-inflammatory properties have been proven in several studies (Alvarez-Suárez et al., 2012; Silva et al., 2013). Nowadays, stingless beekeeping or "meliponiculture" remains a widespread practice in many Latin American countries (Nates-Parra \& Rosso-Londoño, 2013; Paris et al., 2018). Despite the importance attached to their honeys, little has been done to value the resource (de Oliveira, 2013). The introduction of stingless bee honey to the market is limited by the low knowledge of the characteristics that define the quality, as well as the absence of regulations and technical procedures that define the standards.

In Peru, about 170 species of stingless bees have been reported (Rasmussen \& Gonzalez, 2009) and meliponiculture is practiced in an artisanal way by native peoples. Melipona illota Cockerell, Tetragonisca angustula Latreille and Scaptotrigona spp. Moure are commonly raised (Rasmussen \& Castillo, 2003). The quality standards for honey of exotic honeybee (Apis mellifera Linnaeus 1758) have been normed in Peru (NTP 209.168) (Instituto Nacional de Defensa de la Competencia y de la Protección de la Propiedad Intelectual [Indecopi], 2014), while stingless bee honey remains an unknown product. To date, there is hardly a single scientific work to characterize it (Rodríguez-Malaver et al., 2009; Red de Seguridad Alimentaria - Consejo Nacional de Investigaciones Científicas y Técnicas [RSA-Conicet], 2018). The purpose of this study was to determine the physicochemical characteristics and microbiological quality of the honeys produced by Scaptotrigona polysticta, Melipona illota and Tetragonisca angustula in apiaries of San Martin, Peruvian Amazon.

\section{Materials and Methods}

Procedure in the apiaries. The study was carried out in two apiaries in the localities of Tarapoto and Chasuta, a transitional area of the tropical dry-humid forest in Huallaga river basin of San Martin, Peru (Figures 1-2). In June and November 2019, 30 honey samples of S. polysticta

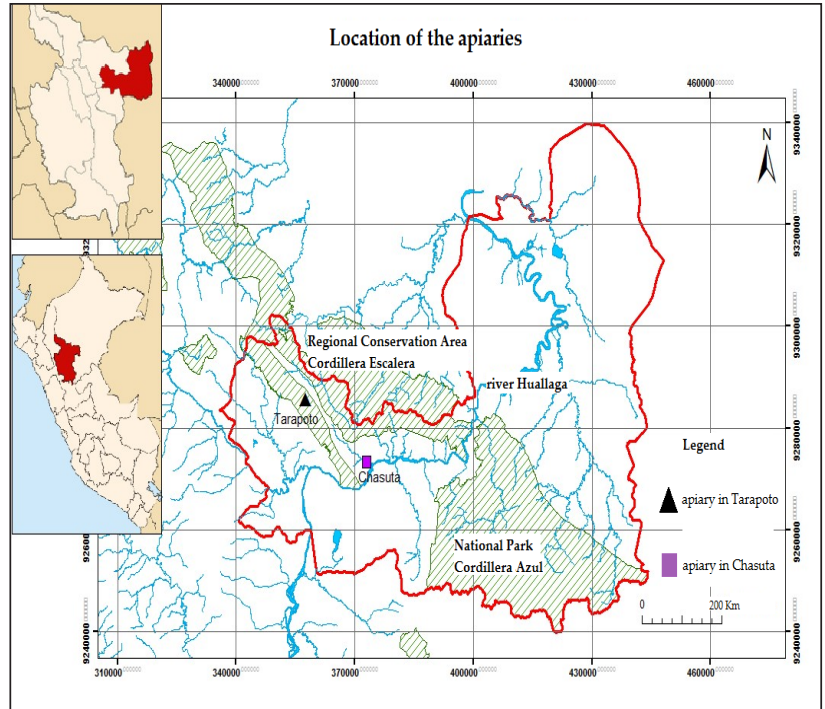

Figure 1. Location of the apiaries.

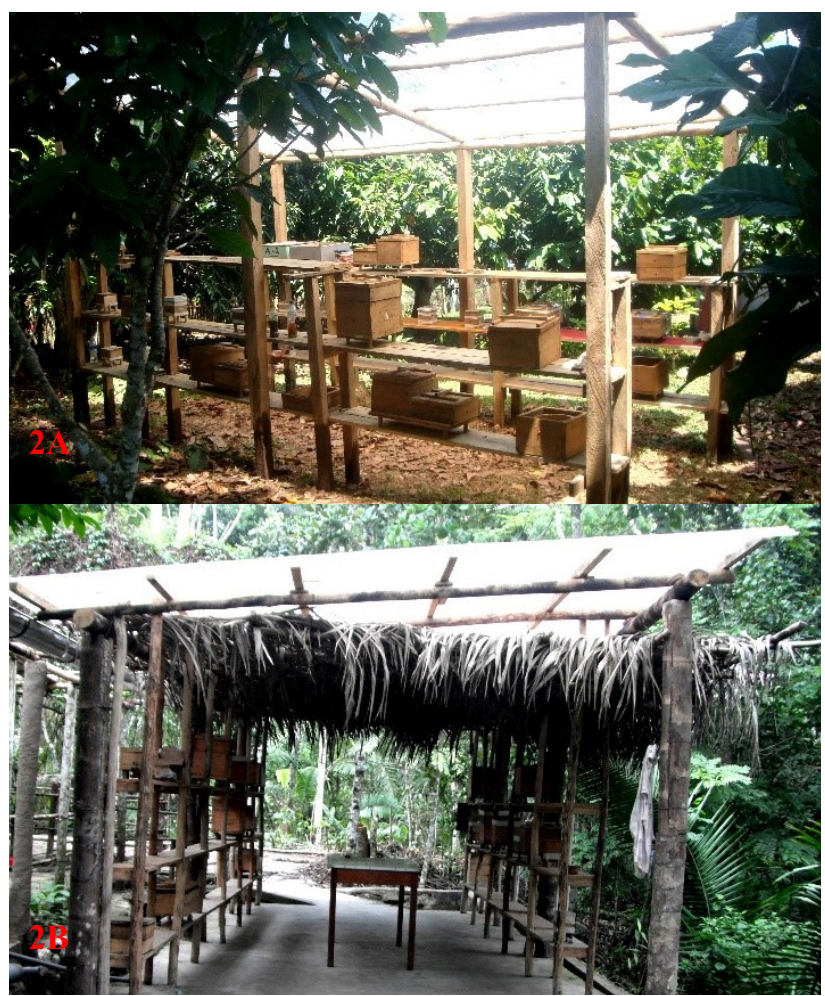

Figure 2. 2.A Meliponario Chasuta. 2.B Meliponario Tarapoto.

$\left(\mathrm{n}_{1}=15\right)$, M. illota $\left(\mathrm{n}_{2}=4\right)$ and T. angustula $\left(\mathrm{n}_{3}=11\right)$ were collected from 24 colonies (Table 1) reared in modern hives. Sterile syringes and a basic glove, lab coat and mask were used to extract the honey. Each sample consisted of the total amount of honey extracted from ten ripe pots randomly chosen within the colonies. The samples were 
stored at a temperature of $4{ }^{\circ} \mathrm{C}$. In the apiary of Chasuta were present only beehives of the species Tetragonisca angustula.

Table 1. Number of honey samples collected by apiary.

\begin{tabular}{lcc}
\hline & Tarapoto & Chasuta \\
\hline S. polysticta & 15 & 0 \\
M. illota & 4 & 0 \\
T. angustula & 6 & 5 \\
\hline
\end{tabular}

Chemical-physical analysis. The analyzes were carried out in the Takiwasi Laboratory, in Tarapoto (http://www. laboratorio.takiwasi.com/). Hydrogen potential $(\mathrm{pH})$ was measured with a $\mathrm{pH}$ meter (Hanna brand, model HI 8424); the total polyphenol content with a spectrophotometer (UNICO brand), according to the procedure described by Meda et al. (2005); and the color, determined according to Instituto Argentino de Normalización y Certificación (Iram, 2007), by means of a Pfund Kohler colorimeter and a spectrophotometer (Unico $\AA$ ). The standards of the United States Department of Agriculture (Usda, 1985) were used to establish the correspondence among $\mathrm{mm}$ Pfund values and color. A field Brixometer (0 - 90\% Brix) (Texim ${ }^{\circledR}$, model TR-099) was used to measure the total solutes. Color and total polyphenols of $M$. illota honey have not been determined due to insufficient sample volume for this analysis.

Microbiological analysis. The colony-forming units $(\mathrm{CFU} / \mathrm{mL}$ ) were counted in plates for: a) aerobic mesophilic organisms, b) anaerobic sulfite-reducing agents (cf. Clostridium perfringens), c) molds and yeasts, according to the following standards from International Organization for Standardization (ISO): 4833-1 (ISO, 2019), 15213 (ISO, 2003) and 7937 (ISO, 2004), respectively. The results were compared with the maximum values allowed by the Peruvian sanitary technical standard NTS № 071-Minsa/ Digesa-V.01 (Ministerio de Salud, [Minsa], 2008).

\section{Data analysis}

The data are expressed as mean \pm standard deviation. A t-Student test was applied for comparison of means. The statistical analyses were performed using Analysis ToolPak for Microsoft Excel 2019 (Microsoft Corporation, Redmond, USA). A p-value $<0,05$ was considered significant.

\section{Results}

Chemical-physical quality. The honeys showed differences in the parameters $\mathrm{pH}$, percentage of total solutes, color, and total polyphenols (Table 2). T. angustula honey presented the highest $\mathrm{pH}$ value $(4,7 \pm 0,6)$ and a high total solute content $(73,0 \pm 2,7 \%)$, compared to the other species. The $S$. polysticta honeys showed a strong variation of color: from light amber to dark yellow, while the samples of T. angustula were all dark yellow (Table 3 ). Total polyphenols were higher in T. angustula honeys compared to that observed for $S$. polysticta samples (Table 4).

Table 2. Main chemical parameters of samples (n) of honey from $S$. polysticta, M. illota. and T. angustula (one day after harvest; conservation at $4^{\circ} \mathrm{C}$ ).

\begin{tabular}{lccc}
\hline & $n$ & $\mathrm{pH}$ & $\%^{2}$ Total solutes \\
\hline S. polysticta & 15 & $3,8 \pm 0,6^{b}$ & $70,4 \pm 2,5^{\mathrm{b}}$ \\
M. illota & 4 & $3,5 \pm 0,6^{\mathrm{c}}$ & $61,2 \pm 3,2^{\mathrm{c}}$ \\
T. angustula & 11 & $4,7 \pm 0,6^{a}$ & $73,0 \pm 2,7^{\mathrm{a}}$ \\
\hline
\end{tabular}

Note: Different letters indicate significance for $\mathrm{p}<0,05$.

Table 3. Values of mm Pfund and color of samples ( $n$ ) of honeys of S. polysticta and T. angustula (seven days after harvest; conservation at $4^{\circ} \mathrm{C}$ ).

\begin{tabular}{lcccl}
\hline Species & $n$ & mm Pfund & Range & Color (spectrum) \\
\hline S. polysticta & 6 & $115 \pm 23^{\mathrm{a}}$ & $77-141$ & $\begin{array}{l}\text { Light amber- } \\
\text { a m b e r - d a r k } \\
\text { yellow }\end{array}$ \\
T. angustula & 5 & $178 \pm 33^{\mathrm{b}}$ & $147-216$ & Dark yellow \\
\hline
\end{tabular}

Note: Different letters indicate significance for $\mathrm{p}<0,05$.

Table 4. Total polyphenol content (TPC) in $\mathrm{mg} / 100 \mathrm{~g}$ for samples (n) of S. polysticta and T. angustula honeys (seven days after harvest; storage at $4^{\circ} \mathrm{C}$ ).

\begin{tabular}{ccc}
\hline Species & $\boldsymbol{n}$ & TPC $(\mathbf{m g} / \mathbf{1 0 0 g})$ \\
\hline S. polysticta & 6 & $8,9 \pm 0,8^{\mathrm{a}}$ \\
T. angustula & 5 & $12,2 \pm 2,8^{\mathrm{b}}$ \\
\hline
\end{tabular}

Note: Different letters indicate significance for $\mathrm{p}<0,05$.

Microbiological quality. Honey samples from $S$. polysticta, M. illota and T. angustula were free of bacterial contamination; but $30 \%$ and $50 \%$ of the samples of $S$. polysticta and $T$. angustula, respectively, exceeded the maximum threshold allowed by the Peruvian sanitary standard for molds and yeasts (Table 5).

\section{Discussion}

The results of this study are consistent with those obtained by other authors (Souza et al., 2006; Fuenmayor et al., 2012; Vit et al., 2016; Lemos et al., 2017; RSA-Conicet, 2018; Grajales-Conesa et al., 2018) in terms of acidity and total solute content. However, the methods of analysis used in the different scientific papers could be distinct, so it would be difficult to make a comparison among our results and another one. In general, the honeys of stingless bees have been characterized by low $\mathrm{pH}$, because the presence of different acids (gluconic, acetic, lactic, citric, succinic, formic, malic, maleic and oxalic), and a reduced total solute content, if compared with Apis mellifera honey (Vit et al., 1998). 
Table 5. Frequency of samples $(F)$ that meet the legal standards of microbiological quality of honey from three species of stingless bees: S. polysticta, M. illota and T. angustula.

\begin{tabular}{|c|c|c|c|c|c|c|c|c|}
\hline \multirow{2}{*}{ Species } & \multirow{2}{*}{$n$} & \multicolumn{2}{|c|}{$\begin{array}{c}\text { RTAM } \\
(\text { UFC/mL) }\end{array}$} & \multicolumn{2}{|c|}{$\begin{array}{c}\text { RTASR } \\
\text { (UFC/mL) }\end{array}$} & \multicolumn{3}{|c|}{$\begin{array}{c}\text { RTML } \\
(\mathrm{UFC} / \mathrm{mL})\end{array}$} \\
\hline & & $\begin{array}{c}\text { Value } \\
\text { ref. }\end{array}$ & $\mathbf{F}$ & Value ref. & $\mathbf{F}$ & Value ref. & $\begin{array}{c}\text { Average } \\
\text { value }\end{array}$ & $\mathbf{F}$ \\
\hline S. polysticta. & 10 & $10^{3}$ & $100 \%$ & $10^{2}$ & $100 \%$ & 10 & 23 & $30 \%$ \\
\hline M. illota & 3 & $10^{3}$ & $100 \%$ & $10^{2}$ & $100 \%$ & 10 & 5 & $100 \%$ \\
\hline T. angustula & 6 & $10^{3}$ & $100 \%$ & $10^{2}$ & $100 \%$ & 10 & 53 & $50 \%$ \\
\hline
\end{tabular}

Note: RTAM: Total aerobic mesophilic count. RTASR: Total anaerobic reduction sulfite count (maximum limit allowed = 102). RTML: Total mold and yeast count (maximum allowed limit $=10$ ). Valor ref.: Maximum threshold allowed by NTS N071-Minsa/ Digesa-V01.

The color of honey, which can usually vary from practically transparent to almost black, reflects the amount of carotenoid, chlorophyll, and xanthophyll pigments (Suescún \& Vit, 2008). The darkest hue of the honeys of $T$. angustula could be related to the major presence of minerals and phenolic compounds (Instituto Nacional de Tecnología Agropecuaria [Inta], 2019), as well as calcium and iron phosphate; while the light colored honeys of $S$. polysticta would prove to be richer in vitamin A (Zandamela, 2008).

Phenolic compounds are not only a marker of the floral origin of the honey, but also potential indicators of their biological activity (Quiñones et al., 2012). In this study, the total polyphenols were much lower than those recorded for the same bee species by Rodríguez-Malaver et al. (2009). However, due to the lack of information about the area of origin and the season of extraction of the samples in this investigation, it was not possible to speculate on the causes of these differences.

Microorganisms in the honey can originate by primary sources, when they come from the nectar or for influence of the bees themselves, and inoculate by secondary sources, when operating conditions influence the collection, transport and storage of honey (Pucciarelli et al., 2014). Absence of mesophiles and sulfite-reducing anaerobic bacteria in all the analyzed samples would indicate the optimal microbiological quality of the honeys. Although the high water content of stingless bees honeys could favor the growth of molds and yeasts (Gil, 2010), the causes of this presence in the samples of $S$. polysticta and $T$. angustula deserve to be studied in depth, without ignoring presence of yeasts in the "bees bread" (Portillo, 2016), the conservation and sanitation conditions of inert laboratory surfaces (Sarmiento et al., 2014) in storage (Ascencio, 2014) and harvest protocols (RSA-Conicet, 2018).

It assumes that several causes could have concurred to observe significant differences among physicochemical parameters of honeys from $S$. polysticta, M. illota and $T$. angustula: changes in floral origin of the honey, the kinds of materials used by different species, the processes of production and storage used for each species, would be considered as the main factors to define the quality of the honey (de Oliveira \& Santos, 2011). Anyhow, these aspects were not part of our study, being a preliminary analysis on the quality of the honeys of some stingless bee species commonly reared in the San Martín region. We believe it should be the following step to deepen the knowledge on the nature of honeys from Peruvian stingless bees.

\section{Conclusions}

The results of this research agree with those obtained in other countries and the absence of bacteria in all the samples analyzed would indicate an optimal microbiological quality. However, the presence of mold and yeast in the $S$. polysticta and $T$. angustula samples deserves to be investigated. The characterization of physicochemical parameters and the microbiological quality are essential to define for the process of setting quality standards of the honeys, providing the reference values. Due to the scant knowledge about the stingless bee honeys in Peru, this study represents a starting point for new research aimed at enhancing stingless bee honeys and boosting the meliponiculture in the country.

\section{Acknowledgments}

To the Research and Development Institute (IID) of the Universidad Nacional de San Martín (UNSM), for financing the research. To the cooperative Mushuk Runa Ltda. and their meliponicultures. To Basilia Miriam Fernández Argudín, for the review of the article. To the Takiwasi Laboratory for the analysis of honey samples. To the team of Estudios Amazónicos and César Guerra Saldaña.

\section{References}

Alvarez-Suarez, J. M., Giampieri, F., Gonzalez-Paramas, A. M., Damiani, E., Astolfi, P., \& Martínez-Sánchez, G. (2012). Phenolics from monofloral honeys protect human erythrocyte membranes against oxidative damage. Food and Chemical Toxicology, 50, 15081516. https://doi.org/10.1016/j.fct.2012.01.042

Ascencio, D. J. (2014). Evaluación de los cambios pre y postcosecha de la miel de especies de abejas sin 
aguijón. [Master's thesis, Universidad Nacional de Colombia]. UNC Repository. https://repositorio. unal.edu.co/handle/unal/52276

Cauich K., R., Ruiz, J. C., Ortiz, E., \& Segura, M. R. (2015). Potencial antioxidante de la miel de Melipona beecheii y su relación con la salud: una revisión. Nutrición Hospitalaria, 32 (4), 1432-1442. http:// dx.doi.org/10.3305/nh.2015.32.4.9312

De Oliveira, E. N., \& Santos, D. (2011). Análise físico química de méis de abelhas africanizada e nativa. Revista do Instituto Adolfo Lutz, 70(2), 132-138. https://doi.org/10.34117/bjdv6n4-144

De Oliveira, R. M. (2013). Production and Marketing of Pot-Honey. In P. Vit, S.R.M. Pedro, \& D. Roubik (Eds.), Pot-Honey. A legacy of stingless bees (pp. 541-556). Springer. https://doi.org/10.1007/978-14614-4960-7

Fuenmayor, C. A., Zuluaga-Domínguez, C. M., DíazMoreno, A. C., \& Quicazán, M. C. (2012). "Miel de Angelita": nutritional composition and physicochemical properties of Tetragonisca angustula honey. Interciencia, 37(2), 142$147 . \quad \mathrm{https}: / / \mathrm{www}$. redalyc.org/articulo. oa? $\mathrm{id}=33922717011$

Gil, A. (2010). Tratado de nutrición: composición y calidad nutritiva de los alimentos. $2^{\mathrm{a}}$. ed. Ed. Médica Panamericana.

Grajales-Conesa, J., Vandame, R., Santiesteban-Hernández, A, López-García, A., \& Guzmán-Díaz, M. (2018). Propiedades fisicoquímicas y antibacterianas de mieles de abejas sin aguijón del Sur de Chiapas, México. Ibciencias, 1(1), 1-7. http://biociencias. unach.mx/ibciencias/doc/articulo1.pdf

Instituto Nacional de Defensa de la Competencia y de la Protección de la Propiedad Intelectual. (2014). Miel: definiciones, requisitos y rotulado (Indecopi NTP 209.168). El Peruano, 8.

Instituto Nacional de Tecnología Agropecuaria. (2019). Guía para la caracterización de mieles argentinas. Buenos Aires: Inta/ Ministerio de Agricultura, Ganadería y Pesca.

Instituto Argentino de Normalización y Certificación. (2007). Miel 15941-2: determinación del color. Parte 2: método Pfund. Buenos Aires, Argentina: Ed. Iram.

International Organization for Standardization. (2019). 4833-1:2013. Microbiology of the food chain - horizontal method for the enumeration of microorganisms, Part 1: Colony count at $30{ }^{\circ} \mathrm{C}$ by the pour plate technique. Geneva, Switzerland: ISO.
International Organization for Standardization. (2004) 7937: Microbiology of food and animal feeding stuffs: Horizontal method for the enumeration of Clostridium perfringens, Colony-count technique. Geneva, Switzerland: ISO.

International Organization for Standardization. (2003). 15213: Microbiology of food and animal feeding stuffs: Horizontal method for the enumeration of sulfite-reducing bacteria growing under anaerobic conditions. Geneva, Switzerland: ISO.

Kerr, W. E., Carvalho, C. A., Silva, A. C., \& Assis, M. G. P. (2001). Aspectos pouco mencionados da biodiversidade amazónica. Parcerias estratégicas, $12,20-41$.

Lemos, M. S., Venturieri, G. C., Dantas Filho, H. A., \& Dantas, K. G. F. (2017). Evaluation of the physicochemical parameters and inorganic constituents of honeys from the Amazon region. Journal of Apicultural Research, 57(1), 135-144. https://doi.org/10.1080/00218839.2017.1338120

Meda, A., Lamien, C. E., Romito, M., Millogo, J., \& Nacoulma, O. G. (2005). Determination of the total phenolic, flavonoid and proline contents in Burkina Fasan honey, as well as their radical scavenging activity. Food Chemistry, 91(3), 571-577. https:// doi.org/10.1016/j.foodchem.2004.10.006

Nates-Parra, G., \& Rosso-Londoño, J. M. (2013). Diversidad de abejas sin aguijón (Hymenoptera: Meliponini) utilizadas en meliponicultura en Colombia. Acta Biológica Colombiana, 18(3), 415-426. https://revistas.unal.edu.co/index.php/ actabiol/article/view/38543

Ministerio de Salud. (2008). Norma sanitaria que establece los criterios microbiológicos de calidad sanitaria e inocuidad para los alimentos y bebidas de consumo humano (NTS № 071-Minsa/Digesa-V.01). https://it.scribd.com/document/395175687/ NTS-071-MINSA-DIGESA-2008-CRITERIOSMICROBIOLOGICOS-pdf

Paris, E. H., Peraza, C., Masson, M. A., Delgado, P. C., \& Escamilla, B. C. (2018). The organization of stingless beekeeping (Meliponiculture) at Mayapán, Yucatan, Mexico. Journal of Anthropological Archaeology, 52, 1-22. https://doi.org/10.1016/j. jaa.2018.07.004

Portillo, C. Y. (2016). Identificación de levaduras presentes en el proceso de transformación de polen corbicular a pan de abejas por métodos tradicionales y moleculares. [Master's thesis, Universidad Nacional de Colombia]. UNC Repository. http://bdigital.unal.edu.co/52640/ 
Pucciarelli, A. B., Schapovaloff, M. E., Kummritz, S., Señuk, I. A., Brumovsky, L. A., \& Dallagnol, A. M. (2014). Microbiological and physicochemical analysis of yateí (Tetragonisca angustula) honey for assessing quality standards and commercialization. Revista Argentina de Microbiología, 46(4), 325-332. https://doi.org/10.1016/S0325-7541(14)70091-4

Quiñones, M., Miguel, M., \& Aleixandre, A. (2012). Los polifenoles, compuestos de origen natural con efectos saludables sobre el sistema cardiovascular. Nutrición Hospitalaria, 27(1), 76-89. https://doi. org/10.3305/nh.2012.27.1.5418

Rasmussen, C., \& González, V. (2009). Abejas sin aguijón (Hymenoptera: Apidae: Meliponini) del Cerro Escalera, San Martín, Perú. Sistemas Agroecológicos y Modelos Biomatemáticos, 2(2), 26-32.

Rasmussen, C., \& Castillo, P. S. (2003). Estudio preliminar de la meliponicultura o apicultura silvestre en el Perú (Hymenoptera: Apidae, Meliponini). Revista peruana de Entomología, 43, 159-164.

Rodríguez-Malaver, A. J., Rasmussen, C., Gutiérrez, M. G., Gil, F., Nieves, B., \& Vit, P. (2009). Properties of honey from ten species of Peruvian stingless bees. Natural Product Communication, 4 (9), 1221-1226. https://doi.org/10.1177/1934578X0900400913

Red de Seguridad Alimentaria - Consejo Nacional de Investigaciones Científicas y Técnicas. (2018). Estándares de calidad microbiológico y físico - químico en miel de abejas nativas sin aguijón (Ansa). Argentina: Conicet.

Sarmiento, P., Gutiérrez, C., \& Hernández, C. (2014). Comparación entre la calidad microbiológica de miel de Tetragonisca angustula y de Apis mellifera. Revista Facultad Nacional de Agronomía Medellín, 67(2): 234-238.

Silva, T. M. S., Santos, F. P., Evangelista-Rodrigues, A., Silva, E. M. S., Silva, G. S., Novais, J. S., Santos, F. A. R., \& Camara, C.A. (2013). Phenolic compounds, melissopalynological, physicochemical analysis and antioxidant activity of jandaira (Melipona subnitida) honey. Journal of Food Composition and Analysis, 29, 10-18. https://doi.org/10.1016/j. jfca.2012.08.010

Souza, B., Roubik, D., Barth, O., Heard, T., Enríquez, E., Carvalho, C., Villas-Bôas, J., Marchini, L., Locatelli, J., Persano-Oddo, L., Almeida-Muradian, L., Bogdanov, S., \& Vit, P. (2006). Composition of stingless bee honey: Setting quality standards. Interciencia, 31(12), 867-875.
Suescún, L., \& Vit, P. (2008). Control de calidad de la miel de abeja producida como propuesta para un proyecto de servicio comunitario obligatorio. Fuerza Farmacéutica, 12(1), 6-15.

United States Department of Agriculture. (1985). United States Standars for Grades of Extracted Honey. Washington, USA: Department of Agriculture, Agricultural Marketing Service.

Vit, P., Fernandez-Maeso, M. C., \& Ortiz-Valbuena, A. (1998). Potential use of the three frequently occurring sugars in honey to predict stingless bee entomological origin. Journal of Applied Entomology, 122, 5-8. https://doi. org/10.1111/j.1439-0418.1998.tb01452.x

Vit, P., González, I., Sorroza, L., \& Pedro, S. R. (2016). Caracterización físicoquímica de miel de angelita Tetragonisca angustula (Latreille, 1811) producida en Esmeraldas, Ecuador. Ciencia Unemi 9(20): 77-84. http://ojs.unemi.edu.ec/index.php/ cienciaunemi/article/view/350

Yáñez-Ordóñez, O., Trujano, M., \& Llorente, J. (2008). Patrones de distribución de las especies de la tribu Meliponini (Hymenoptera: Apoidea: Apidae) en México. Interciencia, 33(1), 41-45.

Zandamela, E. (2008). Caracterización físico - química y evaluación sanitaria de la miel de Mozambique. [Doctoral Dissertation, Universidad Autónoma de Barcelona]. UAB Repository. https://www.tdx.cat/ handle/10803/5701 